\title{
Digital storytelling as a tool for teaching: Perceptions of pre-service teachers ${ }^{1}$
}

\author{
C TIBA, ${ }^{2}$ JCONDY, ${ }^{3}$ A CHIGONA, ${ }^{4}$ AND NTUNJERA ${ }^{5}$
}

\begin{abstract}
It has been shown that teachers are reluctant to use technology despite the South African (SA) government's huge expenditure on technological equipment. This might be the result of teachers being unable to select appropriate technology that will yield positive learning outcomes as well as being ill-equipped to integrate technology into their pedagogy. To this end, pre-service teachers at a University were trained on how to integrate digital storytelling (DST) effectively into their teaching. The aim of this study is to gain insight into the potential benefits of DST for teaching and learning and to determine factors that may prevent pre-service teachers' uptake of DST during in-service practice. This is a qualitative study in which fifty pre-service teachers were divided into five groups for focus group interviews. Data were analysed, and the results show that preservice teachers perceived DST to be beneficial in the classroom as it has the potential to (i) motivate and engage learners, (ii) promote voice/self-expression, and (iii) promote collaborative learning and acquisition of multiple skills. Pre-service teachers are of the opinion that a lack of resources, self-confidence and time owing to restrictive curricula may prevent uptake of DST during in-service teaching. It was recommended that school stakeholders create a balance between intrinsic and extrinsic factors that will promote the adoption and integration of DST into teaching. Also, the education institution concerned strives to balance all three strands of knowledge: technology, pedagogy and content.
\end{abstract}

Keywords: Technology, digital storytelling, technology integration, multimedia, pedagogy, digital native, pre-service teachers

\section{Introduction}

Digital technology has become commonplace as many children are using technology on a daily basis. These children spend most of their time with technological tools such as computers, videogames, digital music players, cell phones and other tools of the digital age (Prensky, 2001: 1). The growth in the use of technology by children has forced school

1. Acknowledgement: The authors are grateful to the Intermediate Senior Phase students of 2013 for their insightful comments and to the staff at CPUT who facilitated the focus group

2. Chantyclaire A. Tiba (corresponding author: 3063369@gmail.com) is a doctoral student at Cape Peninsula University of Technology, South Africa.

3. Prof. Janet Condy is an Associate Professor at Cape Peninsula University of Technology, South Africa.

4. Dr Agnes Chigona is a Research Fellow in the Faculty of Education at Cape Peninsula University of Technology, South Africa.

5. Nyarai Tunjera is doctoral student at the Cape Peninsula University of Technology, South Africa. 
stakeholders in South Africa to deploy technological equipment in classrooms such as tablet phones and smart boards (Guest, 2014). Anecdotal evidence, however, shows that the field of education has seen a slow growth in the use of technology for teaching and learning. One of the reasons may be that teachers seem unable to select appropriate technology that will yield positive learning outcomes and are also ill- equipped to integrate technology effectively during teaching.

Chigona, Condy, Gachago and Ivala (2012:1627) warn that unless pre-service teachers are given clear direction on how to integrate technology into their pedagogy, they will not adopt technology for curriculum delivery. This resulted in a Department of Education in a University of Technology teaching final-year Intermediate Senior Phase (ISP) pre-service teachers of 2013 on how to integrate DST effectively into teaching, as part of the professional development course. The professional development course aims to equip pre-service teachers with skills that they will require to teach effectively and efficiently during in-service practice.

The aim of this article is to gain insight into the potential benefits of DST in the classroom and to determine factors that may prevent the uptake of DST by pre-service teachers during in-service practice. Considering that digital storytelling is cutting-edge and many studies on the subject have been conducted internationally, in South Africa (Condy, Chigona, Gachago \& Ivala, 2012; Chigona, 2013) it is still gaining ground. It is hoped that an article on the potential benefits of DST in the classroom and challenges that may prevent uptake and how these challenges can be addressed, may encourage more teachers to use DST. Also, school stakeholders may gain a better understanding of the benefits of this technological tool in teaching South African learners. These learners come from diverse language backgrounds and they prefer the English language as their language of teaching and learning. Therefore, digital technology may be an appropriate tool as it has the potential to motivate and engage learners, promote self-expression and collaboration as well as to allow learners to acquire multiple skills. According to Dogan (2012), the more school stakeholders know about DST, the more they will tap into its benefits and use it in the classroom.

\section{Research questions}

- What are the perceptions of pre-service teachers of the potential benefits of digital storytelling (DST) as a pedagogical tool?

- What are the perceived barriers by pre-service teachers to up taking digital storytelling (DST) during in-service practice?

To answer the research questions, students who were part of the professional development course at a University of Technology were approached to participate in this study. Of the 75 students, 50 voluntarily accepted being part of this study. The 50 pre-service teachers were divided amongst five lecturers for focus group interviews and the questions asked were semistructured. Data was analysed and emerging themes were related to the research questions (Merriam, 1998:45).

The theoretical framework that underpins this study is Mishra and Koehler's (2005) Technological Pedagogical Content Knowledge (TPCK), a vigorous theoretical framework to understand the knowledge needed for effective integration of technology into teaching. Many educational institutions separate technological knowledge (TK) from content knowledge (CK) and pedagogical knowledge (PK). Mishra and Koehler (2005) argue that good teaching must be interplayed between seven constructs: "CK is knowledge about the actual subject matter that is to be learned or taught"; "PK is deep knowledge about the processes and 
practices or methods of teaching and learning; Pedagogical Content Knowledge (PCK) is knowing which teaching approaches fit the content, and likewise knowing how elements of the content can be arranged for better teaching"; "TK is knowledge about standard technologies such as internet and digital video"; "Technological Content Knowledge (TCK) is knowledge about the manner in which technology and content are jointly related"; "Technological Pedagogical Knowledge (TPK) is knowledge of the existence, components, and capabilities of various technologies as they are used in teaching and learning settings, and conversely, knowing how teaching might change as a result of a particular technology"; "TPCK is the basis of good teaching with technology and requires an understanding of the representation of concepts using technology, pedagogical techniques that use technology in constructive ways to teach content, knowledge of what makes concepts difficult or easy to learn and how technology can help redress some of the problems that students face, knowledge of students' prior knowledge and theories of epistemology; knowledge of how technologies can be used to build on existing knowledge and to develop new epistemologies or strengthen old ones" (Mishra \& Koehler, 2005:1026-1031). The TPCK framework guided the process of collecting data. The above-mentioned seven elements guided the researcher to initiate discourses around Technological Pedagogical Content Knowledge benefits and challenges of DST to learners and teachers.

\section{Literature review}

Three areas influence the literature review. These areas are (1) an overview of DST which gives a general understanding of DST, (2) benefits of DST in the classroom, and (3) factors that may prevent the uptake of technology.

\section{(1) Overview of digital storytelling}

Stories have been an element of the human tradition since the beginning of time (Hastings, 2009). Before the advent of written language, wisdom, knowledge and information were communicated orally through stories (Czarnecki, 2009). According to Maddin (2011:2-3), storytelling is intertwined into our everyday life as people use stories for communication and to share information. Maddin (2011) explains further "that it is through stories that humans understand history, themselves and the world". Today the way we tell stories has changed as stories are integrated, for example, with technology, and this is known as DST. Digital stories are a blend of image and text that focus on tales 'from the heart' (Hayes, 2011:291). Similarly, Stenhouse, Tait, Hardy and Sumner (2013:134) concur that digital stories provide a creative way for people to tell their stories using a mixture of voice, image and music. In addition, the Digital Storytelling Association (2002) describes DST as "the modern expression of the ancient art of storytelling". Yuksel, Robin and McNeil (2011) reiterate that DST derives its "power through weaving images, music, narrative and voice together".

There are different kinds of DST which have been categorised into three types. These are: personal narratives, in which authors tell personal stories which revolve around significant events in their life; stories that inform and instruct, are used primarily to convey instructional material in many different content areas (teachers use it to teach the curriculum); and stories that examine historical events: this type of DST is used to recount historical events (cited in Robin, 2008:224-225). 
In order to produce an effective digital story that instructs, informs or recounts historical events and personal tales, Lambert (cited in Dreon, Kerper \& Landis, 2011:5) identifies seven elements that must be taking into consideration. These elements include:

- a point of view which outlines the perspective from which the story is told;

- a dramatic question that sets the tension of the story by identifying issues to be resolved;

- emotional content which engages the audience through common emotions and themes;

- the gift of using the producer's voice during production: helps the audience to make meaning of images;

- the 'power' of the soundtrack which sets the mood of the story;

- economical balance of the auditory and visual tracks of meaning; and

- pacing which sustains the attention of the audience by establishing and modifying the rhythm of the story.

\section{(2) Benefits of digital storytelling}

DST has drawn attention as an appropriate pedagogical tool which can be used in today's classroom. Hastings (2009) is of the opinion that the importance of integrating DST in education is that learners are having fun while learning. When such indirect learning takes place, learners may reach their full potential. Therefore, the benefits of DST have been categorised into themes. These themes are that DST: (i) has the potential to support learnercentred activities, (ii) promotes the acquisition of multiple skills in learners, (iii) encourages voice/self-expression, (iv) motivates and engages learners, (v) encourages deep reflection, and (vi) encourages collaboration. In the next section, literature is provided/an explanation is provided/a brief description is provided on the six benefits of DST when learners are involved in its production.

\section{i. DST supports learner-centred activities}

DST is a technological tool that has the potential to engage students in learner-centred activities (Barrett, 2005; Hayes, 2011:291) since learners are challenged in creating their own stories. In a study, learners were given an opportunity to take pictures with digital cameras, develop their story based on the pictures taken, produce a film based on the pictures by adding subtitles and a background, and present their stories (Hung, Hwang \& Huang, 2012:371). This means that learners take active responsibility for their learning (Menezes, 2012) which has been proven to improve academic performance (Hayes, 2011:291; Sadik, 2008:487).

\section{ii. DST promotes multiple skills in learners}

DST has the potential to engage learners in both conventional and innovative ways of teaching (Gregori-Signes, 2008). Being literate in the $21^{\text {st }}$ century no longer involves only being able to read and write: learners must be able to download, upload, rip, burn, chat, save, blog, Skype and share information (Mullen \& Wedwick, 2008:66). According to Robin (2008: 224), Sylvester and Greenidge (2009: 287), DST can promote multiple skills. These skills include the ability to:

- communicate with an ever-expanding community, to discuss issues, gather information, and seek help (digital literacy); 
- $\quad$ read, interpret, respond, and contextualise messages from a global perspective (global literacy);

- use computers and other technology to improve learning, productivity and performance (technological literacy);

- understand, produce and communicate through visual images (visual literacy); and

- find, evaluate, and synthesise information (information literacy).

Studies such as those of Chigona (2013: 25) have shown that learners gained technological skills during the production of DST. She revealed that during production, there were learners who had adequate technological skills and those who felt inadequate. Those with expertise in using technological tools helped peers who had difficulties (Chigona, 2013:25). Hence, learners with difficulties improved their technological know-how through assistance from knowledgeable peers. The Campbell study (2012: 390), during the two years of a DST project, showed that learners became comfortable and skilled in the use of technological programs offered by MacBook. Learners continued to use technological programmes for writing homework and for projects.

Digital technologies have the potential to improve learners' writing. According to Hayes (2011: 297), and Hicks, Turner and Stratton (2013), writing is no longer an act of putting words on paper, but writers must use technological tools to communicate their message. The use of technological tools such as DST has been shown to improve writing (Figg \& McCartney, 2010: 1; Michalski, Hodges \& Banister, 2005). In a scenario where learners faced difficulties with constructing phrases, using correct grammar and spelling or vocabulary to crafting sentences effectively, they showed an improvement in their writing when they participated in the production of digital stories (Michalski, Hodges \& Banister, 2005). DST has been found to have a positive effect on Taiwanese English First Language sixth graders' vocabulary, reading comprehension and writing skills (Chuang, Kuo, Chiang, Su \& Chang, 2013). It has been shown that during DST production, learners re-write their stories many times (Rance-Roney, 2008:29). Learners' writing may be improved in the process of rewriting and re-forming their scripts.

iii. DST has the potential to encourage voice/self-expression

Self-expression or voice has been used interchangeably by the researchers to mean 'giving learners a say in how they want to tell their stories'. DST has the potential to encourage students' voice (Alexandra, 2008:101) as learners' views are valued from selecting of a topic, deciding on the use of images to tell their stories and background sound to enhance their narratives (Hayes, 2011:292). Self-expression also occurs when learners present their stories to a global audience (Botturi, Bramani \& Corbino, 2012:11; Reinders, 2011:3), for example, through YouTube, Facebook or via presentations to a community. DST can give voice to struggling learners who find it difficult to communicate in a classroom setting (Botturi, Bramani \& Corbino, 2012:10). This is because learners learn to tell their stories, which may enhance their communication skills.

iv. DST has the potential to motivate and engage learners

Studies such as that by Figg and McCartney (2010:54) have shown that DST has the potential to motivate learners. Their findings revealed that using DST as a technological tool motivated learners to construct their digital stories with enthusiasm. It was noted that learners wrote on a daily basis without noticing it. Michalski, Hodges and Banister (2005) revealed that learners spend more time on tasks required to produce their digital stories because they were motivated to learn new software. 
DST has the potential to engage learners. A study by Campbell (2012:392), in which the learners' level of engagement was measured by time spent on task completion and positive writer self-perception revealed that learners spent more time on the DST project compared to time spent on non-digital writing tasks. Another study by Ivala, Gachago, Condy and Chigona (2013:82) which investigated the potential of DST in enhancing student engagement. Focus group interviews were conducted with 29 pre-service teachers and their facilitators. The result revealed that the production of DST enhanced students' level of engagement with their studies. Pre-service teachers reported that the production of DST extended opportunities for students to study beyond classroom time since they were engaged with the subject matter, both at school and at home.

v. DST encourages deep reflection

DST has been identified as a tool that can encourage deep reflection. In the Sandars and Murray study (2009:442), 12 undergraduate medical students volunteered to use DST as a reflective exercise. The aim was to encourage students to reflect on their experience of first meeting a patient. The students indicated that the process of producing their DST required them to think critically about each image. One participant remarked that

When I was putting mine together [DST], I took photographs from around the area. Rather than just writing a quick essay I actually thought about what I wanted the picture to say.

Similarly, when learners align each paragraph in the storyboard to an image (Sylvester \& Greenidge, 2009:287), they are engaged in deep reflection. In addition, learners have to reflect on how to present the DST so that the potential audience will find it interesting, compelling and engaging (Boase, 2008).

vi. DST encourages collaboration

During DST production, learners are divided into groups which have been proven to be beneficial to learning. This is evident in Chigona's (2013:22) study, which showed that learners gained technological skills because they had to learn from peers who are more skilled (Chigona, 2013:22). The learners learnt how to trust each other enough to ask for assistance. On this point, Chigona concluded that learning was taking place as learners' technological skills were enhanced. In another situation, learners' finished or draft digital stories can be posted on the internet perhaps Facebook, blog or YouTube for comments and suggestions (Reinders, 2011:3). Students may use the comments to gain different perspectives on their stories and to shape their draft stories.

The benefits of DST in the educational setting are vast, as is evidenced from the discourses mentioned. It may be an appropriate pedagogical tool to be used in the classroom. Though the literature has focused on the benefits of DST to learners, it is important to mention that DST may be a valuable tool for teachers. For example, DST can help teachers gain insights into issues of diversity from learners' stories if they are given a task on social issues, thus enabling teachers to gain a better understanding of their learners (Condy, Chigona, Gachago \& Ivala, 2013:281).

\section{(3) Factors that will prevent the uptake of technology}

There have been considerable studies on factors that may prevent the uptake of technology by teachers into teaching (Hutchison \& Reinking, 2011: 324; Obiri-Yeboah, Kwarteng \& Kyere-Djan, 2013: 13). For example, Hutchison and Reinking (2011:324) listed barriers that 
may prevent teachers from using technology. They include: a lack of understanding of how to integrate technology into instruction, professional development related to integrating technology into instruction, understanding of how to evaluate students' ability to use ICTs (Information Communication and Technology), and insufficient time due to high-stakes testing. Cassim and Obono (2011) found that the attitudes of teachers, their perception on the usefulness and ease of use of ICT, their ICT awareness and school location all affect adoption of ICT in the classroom. It is argued by Chigona and Chigona (2010) that other significant factors that hinder integration are personal factors such as insufficient ICT training, social factors as a result of rules that prescribe who can use technology and what it can be used for at schools, and environmental factors such as teachers lacking technical support regarding integrating technology into teaching. Similarly, Ahadiat (2005:228) ranked factors that will prevent teachers from using technology. These factors are: a lack of time, required software, technological support, relevance to course material, latest hardware, administrative support, contribution to professional advancement and interest in technology.

\section{Methodology}

This is a qualitative study that explores pre-service teachers' perceptions of the potential benefits of DST and perceived barriers to DST uptake during in-service practice. Qualitative study gave depth to the research questions.

As part of the Professional Development course in 2013, 75 Intermediate Senior Phase (ISP) students had eight-week workshops on how to integrate DST during in-service practice. At the end of the project, each student made their own digital story. All 75 students were invited verbally to take part in a focus group interview. Of the 75, 50 voluntarily accepted. All 50 pre-service teachers who agreed to be part of this study were divided into five groups among five researchers facilitating the discussion. Semi-structured questions, which were informed by the literature, were used during interviews. Furthermore, classrooms were used as venues for the interviews and each interview was scheduled for an hour. The selection of a university venue was preferred because the teachers participating in the study were registered students at the university. Therefore, organizing a focus group interview at the university was convenient.

Data from the five focus group interviews were audio-recorded and transcribed. The transcribed data were analysed: themes were generated to answer the research questions.

\section{Ethics}

The study followed a rigorous code of ethics to protect the researcher as well as the participants (Denscombe, 2007:141). Permission was requested from the University of Technology ethics committee to collect data. Participants of the research were asked to sign informed consent forms to indicate their participation is voluntary (Glesne, 2011:166). Permission was sought from participants to use an audio recorder during interviews to capture data accurately (Bogdan \& Biklen, 1998:7). Aims and outcomes were continuously discussed verbally with participants to ensure that they understood their role in the research.

\section{Result and discussion}

According to the pre-service teachers, the DST project was enriching. As a result, they believed DST might be an appropriate pedagogic tool which could be used in the classroom as it has the potential to motivate and engage learners, promote voice/self-expression, and collaborative learning or acquire multiple skills. However, the pre-service teachers indicated 
that a lack of resources, self-confidence and time due to restrictive curricula might prevent uptake of DST during in-service teaching. The results of the data collected are discussed under the themes that follow.

\section{Digital story has the potential to motivate and engage learners}

One factor noted by pre-service teachers that would influence them to use DST during inservice practice is that DST has the potential to motivate and engage learners. This is because learners are fascinated by technology because they use it daily. Therefore, teachers integrating technology into their curriculum delivery would motivate these learners. With regard to motivation, one pre-service teacher indicated that:

\section{I think digital storytelling will develop their [the learners'] interest ... keeps them focused in class for a longer period and this is because they use technology every day ... walk around with cell phones in their pockets. They grew up with technology ... so it will motivate them to come to class and study ... yeah.}

Another pre-service teacher added that they would use DST during in-service practice because the visual aspect of DST may motivate learners. The pre-service teacher indicated that "today's learners are visual ... they [learners] like visual stuff ... they like to see things ... like the images ... this [DST] might just motivate them to come to class". This discussion shows that today's learners have grown up using technology: integrating it into the classroom may attract their attention. The Figg and McCartney findings (2010:12) showed that using DST as a technological tool attracted learners' attention as they spent more time on tasks. The visual component of DST might captivate learners' interest, thus increasing their motivation.

DST has the potential to engage learners, as they can be given tasks to do on a subject both at home and at school. On this point, a pre-service teacher reported,

You can give learners tasks on a topic, get them to go to the library to do research, search the internet for music and images ... this [the digital story] will get them engaged both at school and at home as it did to us when we were creating our own digital story.

This finding is in line with the Ivala, Gachago, Condy and Chigona study (2013:85) in which pre-service teachers reported that the production of DST extended opportunities for students to study beyond the classroom time, since they were engaged with the subject matter both at school and at home. A student in the Ivala et al. (2013: 85) study supported this discussion by stating,

\section{I also did most of my work at home, like writing out the story and asking when I came to campus, asking the lecturers maybe to edit and just to check if my story is according to how it's supposed to be ... and I will do the typing on campus.}

\section{Digital storytelling has the potential to give learners voice/self-expression}

DST has the potential to give learners voice in the classroom. According to pre-service teachers, a good teacher must be able to give learners opportunities in the classroom for their voices or opinions to be heard. The pre-service teachers believed that DST may give learners voice when teachers involved them in the production. This is evident in one of the participants' responses: 
... I was thinking we most of the times ... we don't give learners in our classes voice ... as schools, as teachers, as parents we don't really know what our children [learners] are thinking or feeling ... so am thinking we can use digital story as platform where children [learners] have their voices heard because now they are for instance in a classroom - you could have a class do a digital story on any social issue ... they present it in class you know... so it could be a way for learners to voice their views, their feelings and thoughts about social issues or what not, yeah.

Another pre-service teacher added:

You can give them [learners] task on digital story to do, the final product can be presented in class, put on YouTube or Facebook and even show to a church community. These are some of the platforms for their opinions on certain issues to be heard.

The result indicated that giving voice to learners is beneficial to teaching and learning. Hence, DST can be used as a platform to give learners voice. Consistent with the above findings, Robin (2007) and Porter (2006: 28) echoed that voice is given to learners when they publish their stories online to be available to a global audience.

\section{Digital storytelling has the potential to promote collaborative learning}

According to pre-service teachers, DST projects may increase collaboration between learners. During DST projects, learners may be divided into groups to help each other to complete their stories. As a result, learners may learn skills such as sharing diverse views on a subject matter and supporting each other to solve complex tasks. Hence, they learn to trust each other during the process. On this point, the pre-service teacher indicated:

Learners can be divided into groups... they would help each other to complete a task and learn how to respect each other's point of view on a subject matter. Helping each other may build trust between learners. And when learners trust each other, they will interact easily in the classroom.

Since today's classrooms are so diverse, another participant said they were going to use DST to create interactions in the classroom. The pre-service teachers intend to create interactions by doing group or peer work with technology. The pre-service teacher revealed that:

There may be black, white, coloured and Indians mixed in one classroom ... I will put them [different races] in one group for them to brainstorm on a topic and to do the river of life and other related aspects of digital story ... by doing that I want them to learn to tolerate each other ... this skill [working in group] they will need with them for life.

The above findings reveal that putting learners into groups to do digital story tasks may be beneficial to teaching and learning. Studies such as Ivala et al. (2013) have shown that learners benefit from group work as they learn from each other during the production of DST.

\section{Digital storytelling has the potential to promote the acquisition of multiple skills}

According to Robin (2008:224), Sylvester and Greenidge (2009:287), DST has the potential to promote the acquisition of multiple skills in learners. The pre-service teachers indicated that they will use DST in their classrooms because several skills are involved during the production of a single digital story. On this point, a pre-service teacher revealed that: 
I will use digital story because there are many skills involved when learners are given the opportunity to produce it [digital story] ... these skills are reading, writing, critical thinking skills, problem solving skills and technological skills...technological skills because learners will be working with technological hardware and software

Another pre-service teacher added:

...through the process of making a digital storytelling, learners will learn copyright stuff. I will explain to them why they cannot just take images or photos from the internet. They have to reference everything at the end of the story...so yeab they learn these skills.

In addition, pre-service teachers may use DST because learners may develop critical thinking skills. A pre-service teacher reported:

...I will integrate digital storytelling into my teaching because learners will gain critical thinking skills. Learners have to make decisions as to what images will be suitable for their story and also deciding on the genre of music to put in their digital story.

For other participants, DST has the potential to enhance communication skills. A participant indicated:

...to me I will use it to enhance students' communication skills ... there will be learners in our classrooms who don't like talking in class. So with digital storytelling you can put them into groups and assign them different roles ... so with their peers, they may be comfortable to discuss issues.

Pre-service teachers were overwhelmed by the DST project since they acquired many skills. As a result they were certain that with resources at the schools, they might integrate DST into their teaching.

In addition, pre-service teachers reported that they will use DST in their classrooms because it has the potential to develop learners' writing. Learners are given a platform to think about what they will write and how they will write their stories during production. During DST production, learners write many drafts (Rance-Roney, 2008:29) which may improve their writing. A pre-service teacher commented:

During any digital storytelling project, learners will be given an opportunity to write their stories ... they can write on their laptops, computers or using a paper and a pen. In the process of learners writing their stories, they may write so many drafts which may possibly improve their writing. I remember I wrote how many times? Threelfour times ... four times... I got it right the last time. It's never easy and most especially when you're writing in a second language, yeah.

Another pre-service teacher added:

I will use it because it may improve learners' writing. This is because learners tend to write beyond what they are supposed to write and this [digital storytelling] will help in condensing their writing and then keep it to the fact since learners are required to write between 300-500 words. I will definitely use it in the classroom.

According to the pre-service teachers, writing is the most important aspect of DST. Learners learn how to summarise and review their work for consistency. These skills, according to preservice teachers, are needed in the learners' future workplace. Ohler (2006:44) emphasises the importance of writing by indicating that teachers should focus on learners writing their story

Td 11(1), July 20915, pp. 82-97. 
first and then using the story to enhance learners' skills in critical thinking and media literacy when they produce their story.

Although all pre-service teachers perceived DST to be beneficial in the classroom, some might refrain from using it due to a lack of resources, self-confidence or time because of restrictive curricula. Below is a discussion on barriers to the uptake of DST.

\section{Lack of resources}

Firstly, with regard to lack of resources, the pre-service teachers acknowledged that they have acquired the skills required for effective integration of DST during teaching. Lack of technological resources at the schools where they will be teaching would, however, make it difficult for them to integrate DST into their teaching. One pre-service teacher remarked:

... How I wish I was going to use it but unfortunately I wouldn't be able to use it because I will be going to Transkei and rural areas, so there is no technology there even $T V$... there is only one $T V$ in the area so I would definitely not be going to using it.

Some teachers, with their positive experience during the production of DST, claimed that, even if they were to teach in under-resourced schools, they would manage to use some sort of technology. A participant indicated:

\section{I will carry my radio... laptop to school just for them to be exposed to some sort of technology, yeah.}

In line with the above argument, Ahadiat's (2005) findings showed that one barrier to integration of technology might be lack of resources such as technological software and hardware.

\section{Lack of self-confidence}

Secondly, the analysis shows that lack of self-confidence may prevent pre-service teachers from using DST. Few teachers felt that the project did not prepare them sufficiently to teach with DST since they had only eight weeks to complete the project. They were worried that during in-service teaching, they may not be able to apply it in classroom. A pre-service teacher said:

... the digital story thing was new to us ... we never really got the opportunity to be familiar with all the technological tools. The facilitators showed us yeab to get our stories done but we never had time to practise. So I might face challenges implementing it at school because I am not sure I have the confidence yet, yeah.

Another pre-service teacher added:

... and I find that sometimes people are so computer literate or skilled that when they have to show or teach someone something they are so into it that they don't keep track with the fact that you are but slower than what they are, so they just go on. So in the process you don't learn anything.

It was argued by another pre-service teacher that they feel comfortable using other approaches in the classroom than DST. This is because the DST project did not give the preservice teachers enough time to be competent users of the technological tools. The pre-service teacher noted: 
There are many [kinds of] equipment [hardware and software] that I don't know how to use like the photo story because the project was too fast... I wouldn't even try to integrate it in the classroom ... I will use textbook because I am more comfortable with textbook, yeah.

Pre-service teachers believed that if they had had more time to practise with DST, it would have increased their self-efficacy. Thus, the pre-service teachers recommended that coordinators for the DST project should consider starting the project from the first year. This might give ample time for pre-service teachers to gain skills which may boost their selfconfidence to use DST. Pre-service teachers recommended that the education institution where this study was conducted should strive to balance all three strands of knowledge: technology, pedagogy and content. This is because students lacked basic technological knowhow during the DST project which caused delays in the project. Teachers spend time showing learners how to use basic technological hardware and software.

\section{Lack of time}

Thirdly, the greatest proportion of research has shown time to be a major issue in DST projects (Sadik, 2008:502; Bromberg, Techatassanasoontorn \& Andrade, 2013:10). This is because teachers need time to teach learners the many skills already mentioned that are needed to produce a DST. Some students faced difficulties operating technological tools and, as a result, they would needed more time for the teacher to assist them during production (Sadik, 2008: 501). Pre-service teachers complained that the DST project was timeconsuming; they had to work both on campus and at home. Therefore, using DST during inservice practice might require additional time and the pre-service teachers were not sure if they would have enough time to integrate it in the classroom. A pre-service teacher explained their concern:

There were people who struggled to get music during the digital storytelling project... oh yes, there were people who couldn't $O K$ going back to the basics ... there were people who couldn't even go to the internet and find pictures they didn't know how to go to the ... to the internet search engine and then and there were people who couldn't save pictures so and there were people who struggled with say it with finding music [laughing] ... yeah, so basically they were those types of things... imagine you have such learners in your class when you start teaching ... it means introducing digital stories will be time-consuming and difficult.

These discussions reveal that some pre-service teachers lack basic technological knowledge during the DST project. Introducing DST during in-service practice to similar kinds of learners who may lack basic skills is time consuming. This is because learners need extra time to become familiar with the technological hardware and software.

A student added that

...there may be cases were learners are from disadvantage home... they may not know basic things about a computer, so introducing digital storytelling will require a lot of time.

On this point, Bromberg et al., (2013:17) suggest that the teacher can set aside some class time to teach learners how to use the technological equipment required to produce a DST before embarking on a project. 


\section{Conclusions}

Pre-service teachers of this study had first-hand experience of making their own digital storytelling (DST). As a result, they were motivated to use DST during in-service practice. The use of digital stories in a classroom can be an effective tool for teaching and learning as it involves many skills. However, according to the teachers, the deeper impact of digital storytelling is when learners think critically about how to integrate their story with audio and visual components.

Despite the many benefits of DST which may influence teachers' uptake of DST during inservice training, some pre-service teachers believe that a lack of resources, self-confidence and time due to restrictive curricula may prevent their uptake of DST during in-service practice. Pre-service teachers indicated that they might not use technology in the lower grades because learners may not be able to deal with certain social issues and technological equipment. It was argued by the majority of pre-service teachers that teachers could still use DST with lower grades but the theme or topic should be age-appropriate.

In addition, some teachers indicated that they lacked technological knowledge of how to teach with DST although they valued the importance of DST in today's classroom. As a result these teachers plan to undergo further training to augment their skills. It is recommended that teacher education programmes strive to balance all three knowledge streams: content, pedagogy and technology. This is because the pre-service teachers lacked technological compared to content and pedagogical knowledge. Furthermore, to school stakeholders, it was pointed out that they should not only deploy technological equipment in school but they must create balance between extrinsic and intrinsic factors that may encourage teachers to use DST. In schools with technological resources, teachers may still resist integrating DST into their curriculum delivery due to their beliefs, attitude and selfefficacy towards technology.

Limitations of this research/study: The findings cannot be generalised, since the focus is on pre-service ISP teachers of 2013. The result might be different given a different set of students with different experiences of producing DST. As a recommendation for further study, pre-service teachers could be tracked in their classrooms during in-service practice to ascertain the benefits of DST in a classroom setting. This is important as there is a great gap between pre-service and in-service training as teachers perceptions may change based on the school they find themselves.

\section{References}

Ahadiat, N. (2005). Factors that may influence or hinder use of instructional technology among accounting faculty. Campus-Wide Information Systems, 22(4), 210-232.

Alexandra, D. (2008). Digital storytelling as transformative practice: Critical analysis and creative expression in the representation of migration in Ireland. Journal of Media Practice, 9(2), 101-112.

Barrett, H. C. (2005). Researching and evaluating digital storytelling as a deep learning tool. Retrieved from http://www.electronicportfolios.com/portfolios/SITEStorytelling2006. 
Boase, C. (2008). Digital storytelling for reflection and engagement: A study of the uses and potential of digital storytelling. Report Produced as Part of the Phase 1 of The Higher Education Academy / JISC Higher Education e-Learning Pathfinde Programme. Retrieved from http://www.resources.glos.ac.uk/tli/lets/projects/pathfinder/index.cfm

Bogdan, C. R. \& Biklen, K. S. (Ed). (1998). Qualitative research for education: An introduction to theories and methods. ( $\left.3^{\text {rd }} \mathrm{ed}\right)$. California: Allyn \& Bacon.

Botturi, L., Bramani, C. \& Corbino, S. 2012. Finding your voice through digital storytelling. TechTrends, 56(3): 10-11.

Bromberg, N. R., Techatassanasoontorn, A. A. \& Andrade, A. D. (2013). Engaging students: Digital storytelling in information systems learning. Pacific Asia Journal of the Association for Information Systems, 5(1), 1-22.

Campbell, T. A. (2012). Digital storytelling in an elementary classroom: Going beyond entertainment. Procedia-Social and Behavioral Sciences, 69: 385-393.

Cassim, K. M. \& Obono, S. D. E. (2011). On the factors affecting the adoption of ICT for the teaching of word problems. Proceedings of the World Congress on Engineering and Computer Science 2011 (19-21). San Francisco, USA. Retrieved from http://www. ijedict.dec.uwi.edu/include/getdoc.php?id=5073

Chigona, A. (2013). Using multimedia technology to build a community of practice: Preservice teachers' and digital storytelling in South Africa. International Journal of Education and Development using Information and Communication Technology, 9(3), 1727.

Chigona, A. \& Chigona, W. (2010). An investigation of factors affecting the use of ICT for teaching in the Western Cape Schools.18 th European Conference on Information Sysetems.

Retrieved

from

http://www.web.up.ac.za/ecis/ecis2010pr/ecis2010/content/papers/0097

Chigona, A., Condy, J., Gachago, D. \& Ivala, E. (2012). Examining pre-service teachers' perceptions on uptake of digital storytelling for classroom use. In T. Bastiaens \& G. Marks (eds.), Proceedings of World Conference on E-Learning in Corporate, Government, Healthcare, and Higher Education 2012 (1621-1628). Chesapeake, VA: AACE. Retrieved from http://www.editlib.org/p/41839

Chuang, W., Kuo, F., Chiang, H., Su, H., \& Chang, Y. (2013). Enhancing reading Comprehension and writing skills among Taiwanese young EFL learners using digital storytelling technique. Proceedings of the $21^{\text {st }}$ international conference on computers in Education. Indonesia: Asia-Pacific Society for Computers in Education.

Condy, J., Chigona, A., Gachago, D. \& Ivala, E. (2012). Pre-service students' perceptions and experiences of digital storytelling in diverse classrooms. The Turkish Online Journal of Educational Technology, 11(3), 278-285.

Czarnecki, K. (2009). Chapter 1: Storytelling in context. Library technology reports, 45(7), 5-8.

Denscombe, M. (2007). The good research guide for small-scale social research projects. $3^{\text {rd }}$ ed. Berkshire: McGraw-Hill Education. 
Department of Education. (1997). Language in Education Policy. Government Gazette: Pretoria.

Digital Storytelling Association. (2002). The centre for digital storytelling. Retrieved from http://www.dsaweb.org/01associate/ds.html.

Dogan, B. (2012). Educational uses of digital storytelling in K-12: Research results of digital storytelling. In P. Resta (Ed.), Proceedings of society for information technology and teacher education international conference 2012 (1353-13621). Chesapeake, VA: AACE.

Dreon, O., Kerper, R. M. \& Landis, J. (2011). Digital storytelling: A tool for teaching and learning in the YouTube generation. Middle School Journal, 42(5), 4-9.

Figg, C. \& McCartney, R. (2010). Impacting academic achievement with student learners teaching digital storytelling to others: The ATTTCSE digital video project. Contemporary Issues in Technology E Teacher Education, 10(1), 38-79.

Glesne, C. (2011). Becoming Qualitative Researcher: An Introduction. $4^{\text {th }}$ ed. Boston: Allyn \& Bacon.

Gregori-Signes, C. Practical uses of digital storytelling. A pilot project at the university of Valencia. Retrieved from http://www.uv.es/digitalstorytelling/ds

Guest, K. (2014). Western Cape Education News Archive. Retrieved from http://www.itweb.co.za-Western-Cape-Education

Hastings, M. (2009). Digital storytelling: A shareable media in Education. Retrieved from http://www.bamaed.ua.edu/edtechcases/digital\%20storytelling_Case\%2010.

Hayes, C. (2011). “Nihon to Watashi: Japan and myself"-Digital stories to enhance student-

centred Japanese language learning. Electronic Journal of Foreign Language Teaching, 8(1), 291-299.

Hicks, T., Turner, K. \& Stratton, J. (2013). Reimagining a writer's process through digital storytelling. Learning Landscapes, 6(2), 167-183.

Hung, C., Hwang, G. \& Huang, I. (2012). A project-based digital storytelling approach for improving students' learning motivation, problem solving competence and learning achievement. Educational Technology and Society, 15(4), 368-379.

Hutchison, A. \& Reinking, D. (2011). Teachers' perceptions of integrating information andcommunication technologies into literacy instruction: A national survey in the United States. Reading Research Quarterly, 46(4), 305-404.

Ivala, E., Gachago, D., Condy, J. \& Chigona, A. (2013). Enhancing student engagement with their studies: A digital storytelling approach. Scientific Research Online, 4(10A), 82-89.

Maddin, E. (2011). Using TPCK with digital storytelling to investigate contemporary issues in educational technology. Journal of Instructional Pedagogies, 7, 1-11.

Menezes, H. (2012). Using digital storytelling to improve literacy skills. Paper presented at the

International Conference on Cognition and exploratory learning in digital age 2012 (19-21). Madrid, Spain. 
Merriam, S. B. (1998). Qualitative research and case study application. San Francisco: JosseyBass Publishers.

Michalski, P., Hodges, D. \& Banister, S. (2005). Digital storytelling in the middle childhood special education classroom: A teacher's story of adaptations. Teaching Exceptional Children Plus, 1(4).

Mishra, P. \& Koehler, M. J. (2005). Technological pedagogical content knowledge: A framework for teacher knowledge. Teachers College Record, 108(6), 1017-1054, June.

Mullen, R. \& Wedwick, L. (2008). Avoiding the digital Abyss: Getting started in the classroom with YouTube, Digital stories, and Blogs. A Journal of Educational Strategies, 82(2), 66-69.

Obiri-Yeboah, K., Kwarteng, K. O. \& Kyere-Djan, R. (2013). Factors affecting ICT adoption in

tertiary institutions in Ghana: A case of Kwame Nkrumah University of Science and Technology. Information \& Knowledge Management, 3(6), 13-21.

Ohler, J. (2006). The world of digital storytelling. Educational Leadership, 63(4): 44-47.

Prensky, M. (2001). Digital natives, digital immigrants part 1. On the Horizon, 9(5), 1-6.

Rance-Roney, J. (2008). Digital storytelling for language and culture learning. Essential Teacher. 5(1), 29-31.

Reinders, H. (2011). Digital storytelling in the foreign language classroom. ELTWorldOnline.com $3 . \quad$ Retrieved from http://www.blog.nus.edu.sg/eltwo/2011/04/12/digital-storytelling-in-the-foreignlanguage-classroom

Robin, B. R. (2008). Digital storytelling: A powerful technology tool for the $21^{\text {st }}$ century classroom. Theory into Practice, 47, 220-228.

Sadik, A. (2008). Digital storytelling: A meaningful technology-integrated approach for engaged student learning. Educational Technology Research and Development, 56(4): 487-506.

Sanders, J. \& Murray, C. (2009). Digital storytelling for reflection in undergraduate medical education: A pilot study. Education for Primary Care, 20, 441-444.

Stenhouse, R., Tait, J., Hardy, P. \& Sumner, T. (2013). Dangling conversations: Reflections on the process of creating digital stories during a workshop with people with earlystage dementia. Journal of Psychiatric and Mental Health Nursing, 20, 134-141.

Sylvester, R. \& Greenidge, W. (2009). Digital storytelling: Extending the potential for struggling writers. The Reading Teacher, 63(4), 284-295.

Yuksel, P., Robin, B. R. \& McNeil, S. (2011). Educational uses of digital storytelling around the world. In M. Koehler \& P. Mishra (eds.), Proceedings of Society for Information Technology and Teacher Education International Conference 2011 (1264-1271). Chesapeake, VA: AACE. Retrieved from http://www.warehouse.olc.edu/khecrow/webfolder/SITE_DigitalStorytelling 